\title{
Peningkatan keterampilan menulis narasi melalui teknik reka cerita gambar siswa Kelas v sekolah dasar
}

\author{
Siti Maimunah $^{1}$, Hetilaniar $^{2}$, Susanti Faipri Selegi ${ }^{3}$ \\ sitimumun198@gmail.com \\ 1,2,3 Universitas PGRI Palembang
}

\begin{abstract}
Abstrak-- Permasalahan dalam Penelitian ini adalah kurangnya keterampilan menulis karangan narasi. Penelitian ini bertujuan untuk meningkatkan keterampilan menulis narasi melalui teknik reka cerita gambar siswa kelas V Sekolah Dasar. Metode Penelitian ini merupakan penelitian tindakan kelas (Class Room Research) kolaborasi. Subjek pada penelitian ini adalah siswa kelas V SD Negeri 2 Tugu Mulyo tahun ajaran 2020/2021 dengan jumlah siswa 23 siswa. Teknik pengumpulan data dalam penelitian ini menggunakan tes dan observasi. Instrumen dalam penelitian ini adalah instrumen yang berbetuk tes. Teknik analisis data yang diguankan dalam penelitian ini adalah teknik analisis deskriptif kualitatif dengan mencari nilai rata-rata. Penelitian ini dilaksanakan dalam 2 siklus, satu siklus 2 kali pertemuan. Hasil penelitian ini menunjukan adanya peningkatan menulis karangan narasi dalam pembelajaran di kelas. Berdasarkan hasil penelitian disimpulkan bahwa penggunaan teknik reka cerita gambar dapat meningkatkan keterampilan menulis karangan nasari siswa kelas V Sekolah Dasar. Hal ini dibuktikan pada kondisi awal nilai rata-rata siswa 57,69 meningkat pada siklus I yaitu 74.60 sedangkan peningkatan keterampilan menulis karangan narasi pada siklus II yaitu lebih meningkat dengan nilai rata-rata 84,65 . Jadi dapat disimpulakan penggunaan teknik reka cerita gambar dapat meningkatkan keterampilan menulis karangan narasi siswa Sekolah Dasar.
\end{abstract}

Kata Kunci : Keterampilan Menulis; Narasi, Reka Cerita; Gambar

\begin{abstract}
The problem in this research is the lack of skills in writing narrative essays. This study aims to improve narrative writing skills through picture design techniques for fifth grade elementary school students. This research method is a collaborative classroom action research (Class Room Research). The subjects in this study were fifth grade students of SD Negeri 2 Tugu Mulyo for the academic year 2020/2021 with a total of 23 students. Data collection techniques in this study used tests and observations. The instrument in this study is an instrument in the form of a test. The data analysis technique used in this study is a qualitative descriptive analysis technique by looking for the average value. This research was carried out in 2 cycles, one cycle 2 times meeting. The results of this study indicate an increase in writing narrative essays in classroom learning. Based on the results of the study, it was concluded that the use of picture storytelling techniques could improve the writing skills of the fifth grade elementary school students. This is evidenced in the initial conditions the average score of 57.69 students increased in the first cycle, namely 74.60 while the increase in narrative essay writing skills in the second cycle was increased with an average value of 84.65 . So it can be concluded that the use of picture storytelling techniques can improve the narrative essay writing skills of elementary school students.
\end{abstract}

Keyword : Narrative; Writing Skills, Picture; Story Design 


\section{PENDAHULUAN}

Keterampilan

Menulis

merupakan suatu keterampilan berbahasa yang dipergunakan untuk berkomunikasi secara tidak langsung (tidak secara tatap muka dengan orang lain). Menulis merupakan suatu kegiatan yang produktif dan eksprektif. Dalam kegiatan menulis, penulis harus terampil memanfaatkan grafologi, struktur bahasa, dan kosa kata. Keterampilan menulis ini tidak datang secara otomatis, melainkan harus melalui latihan dan praktik yang banyak dan teratur. Dalam penelitian ini keterampilan yang akan di bahas adalah keterampilan menulis narasi. Dalman (2014) menyatakan bahwa narasi merupakan bercerita (cerita), cerita ini berdasarkan urutanurutan atau serangkaian kejadian atau peristiwa.

Hampir setiap jenjang pendidikan yang ada selalu ada pembelajaran menulis. Dalam pembelajaran menulis khususnya kelas V Sekolah Dasar yang terdapat mata pelajaran bahasa materi fiksi yaitu membuat karangan atau narasi. Pada kegiatan menulis tersebut siswa umunya sering kali mendapati kesulitan. Wardarita

(2015)

mengemukakan bahwa faktor kesulitan menulis diantaranya yaitu karena kurangnya membaca, karena membaca dapat dikatakan sebagai kunci dalam menulis dan kurangnya latihan menulis siswa tersebut.

Dalam hal ini pernah diteliti oleh Wagentini (2016) Hasil penelitian yang telah dilakukan adalah terlihat dari analisis data tes keterampilan menulis narasi diketahui bahwa dengan menggunakan teknik reka cerita gambar siswa menjadi lebih mudah dalam mebuat kerangka karangan dengan menentuka isi setiap paragraf, dan dilihat dari hasil wawancara dengan guru bahasa Indonesia diketahui dengan menggunakan teknik reka cerita gambar motivasi siswa dalam belajar menulis mengalami peningkatan khususnya menulis narasi. Selanjutnya ada juga penelitian dari Kuswardana (2015) Hasil penelitian yang telah dilakukan adalah ditunjukkan dengan peningkatan keterampilan menulis karangan narasi pada Siklus I sebesar 4,49, yang kondisi awal 65,17 meningkat menjadi 69,66. Sedangkan 
peningkatan keterampilan menulis karangan narasi pada Siklus II sebesar 11,21, yang kondisi awal 65,17 meningkat menjadi 76,38.

Berdasarkan hasil wawancara yang peneliti lakukan dengan guru kelas V di SD Negeri 2 Tugu Mulyo ditemukan bahwa keterampilan menulis narasi siswa masih sangat rendah, dimana banyak siswa yang belum terampil dalam menulis karangan narasi, dikarenakan pembelajaran yang dilakukan masih bersifat satu arah yaitu pembelajaran berpusat hanya pada guru dan siswa cenderung bersifat pasif dalam kegiatan pembelajaran, guru tidak menggunakan teknik pembelajaran dalam kegiatan pembelajaran menulis karangan narasi, guru hanya menjelaskan karangan narasi melalui ceramah sehingga siswa kesulitan dalam menyususn kalimat.

Aktivitas siswa dalam menulis karangan narasi tergolong rendah dikarenakan masih banyak siswa yang kesulitan dalam menungkana ide atau gagasan dalam karangan narasi mengenai suatu pristiwa yang ditulisnya. Siswa kesulitan meberikan gambaran yang jelas kepada pembaca mengenai urutan rangkaian suatu pristiwa yang diceritakan dalam tulisannya, dan siswa kesulitan menentukan kosakata dalam menyusun kalimat. Menurut Nurgiyantoro (2010) mengemukakan bahwa aspek penilaian hasil menulis karangan narasi meliputi aspek isi, organisasi, kosakata, pengebangan bahasa, dan mekani (ejaan).

Berdasarkan permasalahan yang telah diuraikan diatas maka guru kelas $\mathrm{V}$ bermaksud ingin memperbaiki proses pembelajaran tersebut. Disini peneliti diminta guru untuk membantu memperbaiki pembelajaran menulis karangan narasi agar keterampilan menulis karangan narasi siswa dapat mengalami peningkatan.

Setelah peneliti melakukan wawancara peneliti mengetahui kesulitan siswa dalam menulis karangan narasi dan peneliti berencana membatu memperbaiki proses pembelajaran dengan memperbaiki teknik pembelajarannya yaitu menggunakan teknik reka cerita gambar dalam pembelajaran menulis karangan narasi serta agar 
keterampilan siswa dalam menulis dapat mengalami peningkatan.

Menurut Iriyanti mengemukakan bahwa teknik reka cerita gambar itu sendiri merupakan pembelajaraan bercerita dengan menggunakan media gambar. Gambar yang digunakan dapat berupa gambar satuan atau terpisah atau bisa juga gambar berseri atau berturutan. Melalui teknik reka cerita gambar ini diharapkan dapat menambah kreatifitas dan imajinasi siswa, baik dari keterampilan menulis karangan narasi maupun dari segi minat belajar siswa kelas V Sekolah Dasar tersebut.

\section{METODE}

Metode penelitian yang digunakan oleh peneliti dalam mengumpulkan data adalah metode penelitian tindakan kelas (PTK) Kolaborasi. Menurut Dimas (2018) menyatakan bahwa penelitian tindakan kelas adalah penelitian yang dilakukan oleh guru dikelasnya sendiri dengan jalan merencanakan, melaksanakan, dan merefleksikan tindakan secara kolaboratif dan partisipan guna meningkatkan hasil belajar siswa.
Dalam

pelaksanaanya, penelitian ini dilaksanakan secara kolaborasi antara peneliti dengan guru. Disini peneliti hanya bertindak sebagai observer atau observator dan guru kelas bertindak sebagai pengajar.

Rancangan penelitian ini terdiri atas empat rangkaian kegiatan yang dilakukan dalam siklus berulang. empat tahap kegiatan utama yang ada pada setiap siklus, yaitu perencanaan, pelaksanaan, observasi dan refleksi. Jadi satu siklus dari tahap penyusunan rancangan sampai refleksi yang tidak lain adalah evaluasi. Apabila dikaitkan dalam bentuk tindakan maka yang dimaksud tindakan adalah siklus tersebut. Berikut bentuk rancangan siklus pada penelitian ini.

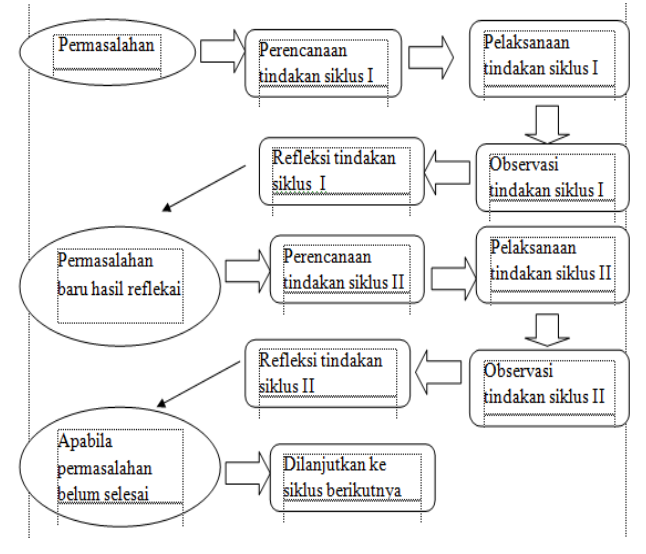


Tes dan observasi yang meningkatkan keterampilan menulis dilakukan pada saat dilakukan narasi pada siswa kelas $\mathrm{V}$.

penelitian di kelas V SDN 2 Tugu Mulyo Kecamatan Lempuing Kabupaten OKI menjadi sumber data penelitian. Seting dalam penelitian ini adalah di SD Negeri 2 Tugu Mulyo Kabupeten Ogan Komering Ilir. Teknik dan alat pengumpulan data dalam penelitian ini menggunakan teknik tes dan observasi. Teknik validasi instrumen dalam penelitian ini yaitu Instrumen yang harus mempunyai validitas isi (content validity) adalah dalam instrumen yang terbentuk tes (Sugiyono, 2010).

Untuk menghitung adanya peningkatan kemampuan menulis narasi melalui teknik reka cerita gambar pada siswa kelas kelas $\mathrm{V}$ SDN 2 Tugu Mulyo Kecamatan Lempuing Kabupaten OKI, digunakan data rangkaian siklus pertama, siklus kedua dan siklus ketiga (jika diperlukan). Kriteria keberhasilan tindakan dalam penelitian ini yaitu jika nilai siswa $80 \%$ mencapai ketuntasan maka dapat disimpulkan bahwa penggunaan teknik reka cerita gambar dapat

\section{HASIL DAN PEMBAHASAN}

Kekurangan maupun kelebihan dijadikan acuan untuk melaksanakan tindakan selanjutnya, berikut kekurangan yang muncul pada siklus I antara lain, Dalam pembelajarn menulis karangan narasi kelas V SDN 2 Tugu Mulyo banyak mengalamai kendala. Diawali dari menulis kalimat siswa sudah kurang kreatif sulit mendapatkan ide, sehingga kalimat yang dibuat lebih banyak meniru teman, dari buku atau mengulang kembali, contoh dari kalimat guru yang sudah pernah disampaikan. Apa lagi jika mereka menyusun kalimat menjadi paragraf semakin kesulitan. Sering mengulang kalimat-kalimat yang ditulis sebelumnya. Sehingga ketika siswa harus menyelesaikan karangan sampai beberapa paragraf tampak sekali hasilnya sangat tidak memuaskan karena menjadi karangan yang tidak koheren dan tidak padu, karena susunannya banyak mengulang kata - kata sebelumnya.

Berdasarkan hasil refleksi dan observasi pelaksanaan tindakan siklus 
I diketuahi bahwa guru kurang mengkondisikan kelas, suara guru juga kurang keras sehingga siswa tidak mendengar ucapan sang guru. Namun penggunaan teknik reka cerita gambar dapat meningkatkan keterampilan menulis karangan narasi siswa kelas V SDN 2 Tugu Mulyo. Dapat dilihat dari kondisi awal nilai rata-rata siswa yaitu 57,69 meningkat menjadi 74,60. Dengan demikian keterampilan menulis karangan narasi siswa mengalami peningkatan.

peningkatan nilai rata-rata siswa pada kondisi awal 57,69 mengalami peningkatan pada siklus I yaitu 74,60. Lebih jelas peningkatannya dapat dilihat pada gambar diagram dibawah

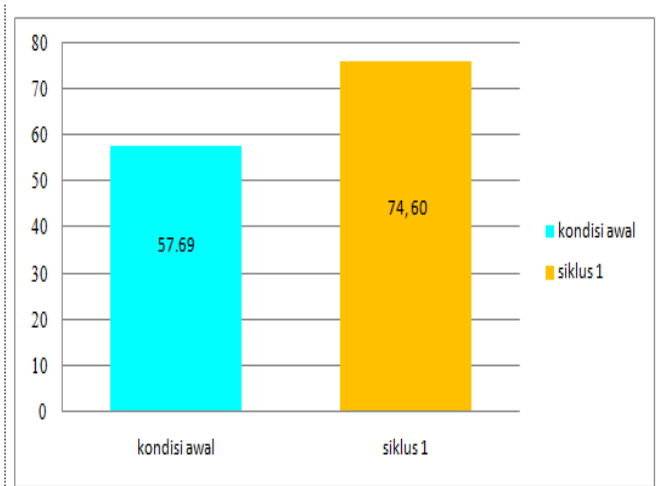

dapat dilihat bahwa nilai rata-

rata siswa mengalami peningkatan yaitu sebesar 16,91 dari kondisi awal 57.69 meningkat pada siklus I menjadi 74,60. Jadi keterampilan menulis karangan narasi melalui teknik reka cerita gambar siswa kelas V SDN 2 Tugu Mulyo mangalami peningkatan.

Berdasarkan hasil refleksi dan observasi pada Siklus II, melalui teknik reka cerita gambar atau media gambar seri dapat meningkatkan keterampilan menulis karangan narasi siswa kelas V SDN 2 Tugu Mulyo. Hal ini tampak saat guru menjelaskan media gambar seri siswa terlihat senang dan antusias mengikuti pembelajaran. Adanya peningkatan aktivitas siswa dan guru dalam proses pembelajaran melalui teknik reka cerita gambar berdampak positif pada keterampilan menulis karangan narasi siswa. Keterampilan siswa dalam menulis karangan narasi mengalami peningkatan pada Siklus II dibandingkan pada Siklus I.

Penggunaan teknik reka cerita gambar dapat meningkatkan keterampilan menulis karanga narasi siswa kelas V SDN 2 Tugu Mulyo nilai rata-rata siswa mengalami peningkatan yaitu, dari kondisi awal 57,69 meningkat pada siklus I menjadi 74,60, dan pada siklus II mengalami peningkatan yang lebih baik lagi yaitu 84,65 . Berikut 


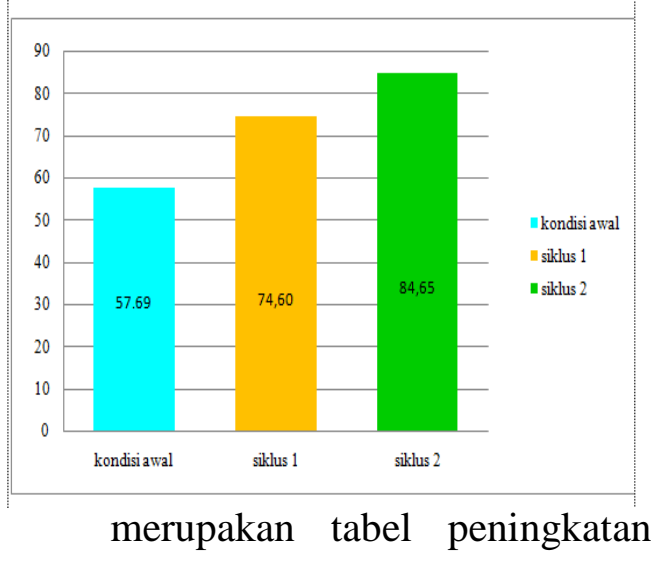

nilai rata-rata siswa pada siklus II.

Grafik diatas menunjukan bahwa nilai rata-rata siswa mengalami peningkatan yaitu sebesar 16,91 dari kondisi awal 57.69 meningkat pada siklus I menjadi 74,60. Selanjutnya pada siklus II ini nilai rata-rata siswa mengalami peningkatan yaitu sebesar 10,05 dari siklus I 74,60, lebih meningkat pada siklus II menjadi 84,65. Jadi keterampilan menulis karangan narasi melalui teknik reka cerita gambar siswa kelas V SDN 2 Tugu Mulyo mangalami peningkatan yang jauh lebih baik.

Teknik reka cerita gambar merupakan pembelajaran bercerita berdasarkan media gambar. Gambar yang digunakan dapat berupa gambar satuan atau terpisah atau bisa juga gambar berseri atau berturutan. Melalui teknik reka cerita gambar ini diharapkan dapat menambah kreatifitas dan imajinasi siswa (Irianti, 2017).

Penelitian ini menggunakan penelitian tindakan kelas (PTK) kolaborasi yaitu peneliti berkolaborasi dengan guru kelas $\mathrm{V}$ SDN 2 Tugu Mulyo dimana peneliti hanya bertindak sebagai observer atau observator lalu guru kelas yang melakukan pembelajaran menggunakan teknik reka cerita gambar lalu guru juga yang memberikan tes menulis karangan narasi kepada siswa. Dalam penelitian ini ada dua siklus yang digunakan yaitu siklus I dan siklus II.

Pada siklus I siswa yang mendapat nilai diatas KKM meningkat menjadi 11 siswa dengan nilai rata-rata 74,60 dibandikan pada kondisi awal nila rata-rata siswa hanya 57,69 dan hanya ada 2 siswa yang nilainya mencapai KKM. Pada sikus I ini sudah tergolong cukup baik, tetapi guru kurang puas dengan hasil yang didapatkan oleh siswa meskipun ada beberapa siswa yang sudah mencapai nilai KKM. Lalu peneliti dan guru melakukan refleksi untuk melaksanakan tindakan 
berikutnya dengan merevisi masalahmasalah yang ada pada siklus I. Berdasarkan hasil observasi dan refleksi didapat permasalahan dalam siklus I yaitu masih ada beberapa siswa yang masih mengalami kesulitan dalam menentukan pokok pikiran, mengemukakan gagasan, kesalahan dalam penulisan kata dan gaya bahasa, namun penggunaan teknik reka cerita gambar dapat menarik perhatian sebagian besar siswa kelas V di SDN 2 Tugu Mulyo untuk mengikuti pembelajaran, sehingga siswa dapat mengikuti instruksi guru dan mulai bisa menulis karangan narasi. Pada siklus I ini nilai rata-rata siswa telah mencapai kategori cukup baik di bandikan pada kondi awalnya.

Pada tindakan siklus II ini dilaksanakan dalam dua pertemuan, tindakan yang disusun pada Siklus II ini tidak jauh berbeda dengan Siklus I, namun dengan Tema yang berbeda dan lebih menarik. Tema yang digunakan yaitu "Bencana Alam". Pada Siklus II ini siswa telihat lebih aktif dalam mengikuti kegiatan pembelajaran. Siswa memperhatikan penjelasan guru, bertanya apabila tidak paham, berani maju ke depan kelas untuk membacakan hasil tulisannya. Dan pada siklus II ini siswa yang mendapat nilai diatas KKM lebih meningkat yaitu sebanyak 21 siswa dengan nilai rata-rata 84.65. jadi dapat disimpulkan bahwa dengan menggunakan teknik reka cerita gambar dapat meningkatkan keterampilan menulis karangan narasi siswa kelas V SDN 2 Tugu Mulyo. Dapat dilihat dari kondisi awal dengan nilai rata-rata 57,69, selanjutnya pada siklus I dengan nilai rata-rata 74,60, dan pada siklus II meningkat dengan nilai rata-rata 84,65 .

Dari hasil analisis data didapatkah bahwa keterampilan menulis karangan narasi dengan menggunakan teknik reka cerita gambar mengalamai peningkatan. Hasil penelitian ini sejalan dengan penelitian yang dilakukan oleh Iriyanti (2017) yang menyatakan bahwa dengan menggunakan teknik reka cerita gambar berseri pada pembelajaran keterampilan menulis narasi menunjukan siswa lebih termotivasi dan tertarik, siswa tidak lagi kesulitan dalam menuangkan ide 
kedalam tulisan serta siswa semakin terampil dalam menulis.

\section{KESIMPULAN}

Berdasarkan hasil penelitian
dapat disimpulkan bahwa
pembelajaran melalui teknik reka
cerita gambar dapat meningkatkan
keterampilan menulis karangan narasi
siswa kelas $\mathrm{V}$ Sekolah Dasar.
Peningkatan keterampilan menulis
karangan narasi yang semula pada
kondisi awal hanya 2 siswa yang

kondisi awal hanya 2 siswa yang mencapai nilainya KKM. Setelah dilakukan tindakan pada siklus I nilai siswa yang mencapai KKM meningkat menjadi 11 siswa, dan pada tindakan siklus II nilai siswa yang telah mencapai KKM lebih meningkat sebanyak 21 siswa. Hal tersebut ditunjukan dengan peningkatan keterampilan menulis narasi siswa pada kondisi awal nilai rata-ratanya 57,69 meningkat pada siklus I yaitu 74,60 sedangkan peningkatan keterampilan menulis karangan narasi pada siklus II yaitu dengan nilai rata-rata 84,65 .

\section{DAFTAR PUSTAKA}

Dalman. (2014). Keterampilan Menulis . Jakarta: PT Raja Grafindo Persada.

Dimas. (2018). Peningkatan Kompetensi Prefesional Guru Melalui Penelitian Tindakan Kelas. Jurnal pendidikan dasar, $18,2$.

Irianti, M. (2017). Peningkatan Keterampilan Menulis Narasi Melalui Teknik Cerita Gambar Berseri Pada Siswa Kelas III SD Negeri Guwo. Jurnal Pendidikan Dasar, 4, 3

Kuswardana, Arif. (2015).

Peningkatan Keterampilan Menulis Karangan Narasi Menggunakan Media Gambar Seri Pada Siswa Kelas III SD N 2 Gaden Klaten Yogyakarta. Skripsi.

Nurgiyantoro, B. (2010). Penelitian Pembelajaan Bebasis

Kompetensi. Yogyakarta: BPFE Yogyakarta.

Sugiyono. (2010). Metode Peneliotian Pendidikan

(Pendekatan Kuantitatif,

Kualitatif Dan R\&D). Bandung: Alfabeta CV

Wagentini, L. (2016). Keterampilan Menulis Narasi Melalui Teknik Reka Cerita Gambar Siswa Kelas VIII SMP Semendo Barat Laut Kabupaten Muara Enim. Skripsi 
Wardarita, R. (2015). Kajian Bahasa

dan Sastra Indonesia.

Yogyakarta: Elmatera. 